\title{
THE WEB-BASED REAL ESTATE MULTIPLE CRITERIA NEGOTIATION DECISION SUPPORT SYSTEM: A NEW GENERATION OF DECISION SUPPORT SYSTEMS
}

\author{
Vita URBANAVIČIENE் $1 \bowtie$, Artūras KAKLAUSKAS ${ }^{2}$, \\ Edmundas K. ZAVADSKAS ${ }^{3}$ and Mark SENIUT ${ }^{4}$
}

${ }^{1}$ Department of Construction Economics and Property Management, Vilnius Gediminas Technical University, Sauletekio al. 11, LT-10223 Vilnius, Lithuania

E-mail:vitaur@st.vgtu.lt

2 Department of Construction Economics and Property Management, Vilnius Gediminas

Technical University, Sauletekio al. 11, LT-10223 Vilnius, Lithuania

3 Department of Construction Technology and Management, Vilnius Gediminas

Technical University, Sauletekio al. 11, LT-10223 Vilnius, Lithuania

4 Research Institute of Internet and Intelligent Technologies, Vilnius Gediminas

Technical University, Sauletekio al. 11, LT-10223 Vilnius, Lithuania

Received 11 February 2009; accepted 7 July 2009

\begin{abstract}
The negotiations are an inseparable part of the real estate buying and selling process. Currently real estate are characterized by the intensive creation and use of information, knowledge and automation (software, knowledge and decision support systems, neural networks, etc.) applications. It is commonly agreed that a better integration of information, knowledge and automation applications, as well use of voice stress analysis (one of biometric technologies) might be an efficient mean for decision making in real estate negotiations. Voice stress analysis can help the negotiators to distinguish between truth and lies, improve the value of decisions made, significantly speed up real estate sector processes, help to reach a better real estate sales and purchase agreement terms and decrease the overall cost of real estate search and negotiation processes. The authors' objective is to improve the quality and efficiency of decision support systems. The article analyses scientific research related to negotiations and presents the developed Web-based Real Estate Multiple Criteria Negotiation Decision Support System with integrated voice stress analysis- a new generation of Decision Support Systems.
\end{abstract}

KEYWORDS: Real estate; Negotiation decision support system; Voice stress analysis

\section{INTRODUCTION}

The real estate sector was always one of the most important branches in Europe: historically, the growth of the construction and real estate sectors considerably affects the general growth of a country's economy. However, Information Technologies (IT) is less used in real estate (RE) when compared to other industries, and IT is rarely integrated. A number of EU countries consider IT applications in the real estate sector as one of the paramount tasks to be completed for successful results.

Under the traditional system, the real estate agent offers a package of services: showing homes, advising sellers on how to make 
the house more marketable, assessing current market conditions, providing information about home values and neighborhoods, matching buyers and sellers, negotiating the sale price, signing contracts, arranging for inspections, and assisting with closings, and so on.

The Internet and intelligent technologies can disaggregate the above services: the Internet searches for real estate, finds alternatives and prepares comparative tables, databases that provide information about real estate, their values and neighborhoods, match buyers and sellers, negotiate the sale price, assist with real estate selection, and lender selection, provides smart software for boilerplate contract's language, and personalized websites that manage complicated transactions.

In a rapidly changing real estate market conditions and the large demand and supply for real estate, it is difficult to adequately orient all the above in the existing situation and to make rational decisions without the help of intelligent systems, knowledge and data bases. IT is transforming entire industries, including the real estate sector; information is a very important factor in activities of the latter (Crowston and Myers, 2004). Currently the global demand for e-negotiations is huge, and web-based negotiation systems are being developed.

Use of voice analysis (one of biometric technologies) might be an efficient mean for decision making in construction and RE negotiations. Voice analysis can help the negotiators to distinguish between truth and lies. Voice stress analysis (VSA) is lie detection technology, which records psychophysiological reaction to stress affecting human voice (Hopkins et al., 2005).

The developed Web-based Real Estate Multiple Criteria Negotiation Decision Support System was based on the best achievements of foreign scientists (taken from the literature review on negotiation research and negotiation support systems), as well as on the created real estate negotiation model (see Urbanavičienè et al., 2009) and the results of voice stress analysis performed by the authors in Vilnius Gediminas Technical University.

This paper is structured as follows. A brief analysis of the main scientific fields dealing with negotiations, multiple criteria decision making and negotiation decision support systems (in Section 2) as well voice stress analysis (in Section 3) is provided as an example below. In Section 4 the created Web-based Real Estate Multiple Criteria Negotiation Decision Support System is presented and described as well a comparative description of testing the developed system is provided. Finally, some concluding remarks are provided in Section 5.

\section{GAME THEORY, ECONOMIC THEORY, MULTIPLE CRITERIA DECISION ANALYSIS AND NEGOTIATION ANALYSIS IN
NEGOTIATIONS}

Initially, negotiations used to be analysed as part of the game theory (branch of applied mathematics). The book by Von Neumann and Morgenstern (1944) Theory of Games and Economic Behaviour started the contemporary game theory. Neale and Bazerman (1991) state that game theorists make assumptions about human nature and then mathematically deduce the results of a negotiator's choice. This theory analyses the consequences of negotiators' decisions, as well as the interaction of risk, common environment and a choice either to cooperate or to refuse cooperation considering the behaviour of other individuals. While studying negotiations, the game theory deals with a number of games; here, the games are often classified as zero-sum games, in which a gain of one individual means loss for another, and non-zero-sum games, in which all players may win on a basis of individual decisions, as well as cooperative games when coalitions are possible and non-cooperative games which follow the rule of antipathy (Pearce, 2006). 
Zavadskas et al. (2004), Peldschus (2005, 2009), Meszek (2008) and Turskis et al. (2009) analysed possibilities to apply the game theory methods in tasks related to construction technology and management, and demonstrated that typical tasks of construction technology and management correspond to zero-sum games of two persons. Zavadskas et al. (2008a) applied multi-criteria selection of contractor in a competitive environment using the game theory. Antuchevičienè et al. (2006) researched into modelling of tasks for refurbishment projects through use of the game theory methods. The results proved the game theory methods suitable for efficient solution of other similar tasks. Lately, scientists are analysing how the game theory could be used in the negotiation process of the client and contractor (Murtoaro and Kujala, 2007). Keršulienè and Urbanavičienè (2007) analysed selection of a way to solve disputes between the client and contractor applying the game theory methods.

Game theory proved its usefulness in analysis of economic behaviour (Pearce, 2006). Game theory provides a framework for analysing interdependent decision-making, for example, when the real estate buyer and seller or the client and contractor make rational and individual decisions independently of each other but their individual decisions interact to determine the payoff of each negotiating party. Full descriptions of the possible courses of each party's action make "strategies" (Raiffa, 1982). However, analysis based on game theory rests on the assumption that all negotiating parties have complete information of the other party's choices, which is seldom the case in the real world (Murtoaro and Kujala, 2007).

Game theory gave birth to utility theory, which, in turn, was expanded by adding multi-attribute utility theory, in which Keeney and Raiffa highlighted priority models based on theories of Von Neumann and Morgenstern (Keeney and Raiffa, 1993) and which is one of the main instruments for negotiation analy- sis. The multi-attribute utility theory is part of multi-criteria decision analysis (MDA). Numerous concepts of game theory were applied in MDA; therefore, the rise and evolution of game theory was useful for multi-criteria decision analysis (Figueira et al., 2005).

Economic theory is applied in negotiation studies to examine the creation of the negotiation mechanism, to analyse experiments, as well as to study price and market mechanisms. Whereas negotiations are a price-determining market mechanism, microeconomics dwelt on numerous features of negotiations (indifference curve, transaction curve and economic pricing strategies, which can be used to validate the tactics of negotiators) (Pearce, 2006).

Development of the negotiation mechanism enabled to suggest auction protocols (Ströbel, 2001). Created at the beginning of the 1960s, the auction theory is one of the major achievements of microeconomics and game theory. Negotiations are often identified with auctions (Ströbel, 2000).

Brzeski (2005) forecasts that one of possible future RE purchase-sale scenarios may be full replacement of traditional $\mathrm{RE}$ agent services, including consulting on funding and insurance, moving towards direct internet contacts. The last phase of this scenario might be complete transfer of real estate auctions to the internet. In such case, ISP would offer customer-specific services of web-based RE search or transactions. Specific segment of services would be bought via internet from brokers ( $\mathrm{RE}$ valuation, negotiation support, agency), attorneys, legal consultants, construction experts, surveyors and providers of other market services.

Decision analysis (DA) and Multiple criteria decision analysis (MCDA) are first and foremost related to behaviour of individuals, thus the decision-making theory and research are of interest to disciplines dealing with behaviour: psychology, economics, management, law, etc. Through statistical and other methods DA tries to find out how negotiators make 
decisions and how optimal these decisions are. Raiffa was a pioneer in the creation of field now generally known as decision analysis. The recent comprehensive book analysing MCDA is Multiple criteria decision analysis edited by Figueira, Greco and Ehrgott (Figueira et al., 2005).

A rather simple act of decision-making actually is a complex process of negotiations and planning (Brown, 2005). As Clemen (1996) states, decision analysis (DA) is the systematic decomposition and clarification of a decision problem when the payoffs of one party do not depend on the decisions of other involved parties, anticipating an entity's actions. It proceeds by structuring and sequencing a party's choices and random events, then separating and subjectively assessing probabilities and values, as well as risk and preferred time. An expected utility criterion is used to aggregate these elements by ranking possible courses of action to determine the optimal variant (Murtoaro and Kujala, 2007).

DA helps an individual negotiator to make individual decisions. The perspective of individual decision-making can help to get a general idea of the setting of an RE development and construction project and to guide behaviour of the client and contractor - primarily driven by own interests - towards joint benefits. It also enables comparison of the benefits of a joint agreement with a separate unilateral action (Murtoaro and Kujala, 2007). The decision analysis gave birth to the negotiation analysis.

Negotiation Analysis (NA) is a logically consistent, complete framework oriented around the perceptions of the zone for possible agreement (Sebenius, 2002; Young, 1991). Theoretical aspects of the approach join the three main research areas, i.e. the game theory, the decision analysis and the behavioural decision theory, all of which are generally based on the ideal of rational decision-making (Raiffa, 1982).
Analytical models used in NA are built on the essential premise that a model's elements may change with time or be changed on purpose by behaviour, creativity and other actions of the negotiating parties. Besides, each party is assumed to have determined the best alternative to negotiated agreement (BATNA), i.e. the best course of specific actions (Ehtamo et al., 2004).

The main advantage of NAA is simple systematic analysis. The disadvantage of the approach is that it mostly relies on the ideal of rational behaviour (Raiffa, 1982). Presuming that decision-making is rational, the negotiating parties always calculate, i.e. set their own tasks, list their alternatives, assess them and select the best or the "optimal" alternative (Pearce, 2006). Issues related to interpersonal and intercultural relations, tone of negotiations, different personalities, motivation and other similar aspects of negotiations are not defined (Sebenius, 2002). Another positive aspect is that mutual open sharing of correct information and creativity help the parties to find their integration potential (Pruitt, 1995). When there is trust, the parties assume that other negotiating parties will not take an opportunistic approach and may reveal more information; therefore, better contracts are possible, which, in turn means, yet more trust (Raiffa et al., 2002; Turel and Yuan, 2008).

\subsection{Electronic negotiation systems}

Negotiations mean decision-making. Advanced technologies used in negotiations help to make the decisions. The scientific literature describes various types of negotiation decision support systems (NDSS) (Rangaswamy and Shell, 1997; Chiu et al., 2005; Vetschera et al., 2006; Kersten and Lai 2007a; Agrawal and Chari, 2009). NDSS are often classified according to the level of (analytical) support to negotiators (Vetschera, 2007).

According to Ströbel and Weinhardt (2003), Kersten and Lai (2007a) and Kim et al. (2007), 
the software and systems described in scientific literature and designed to assist negotiators and to automate negotiations include: decision support systems (DSS), group decision support systems (GDSS), negotiation decision support systems (NDSS), meeting support systems (MSS), negotiation software agents and negotiation software agents-assistants. All of them now are commonly classified as electronic negotiation systems (ENS) (Ströbel and Weinhardt, 2003; Kersten and Lai, 2007a).

For the purpose of decision support systems (DSS) for negotiations creation, negotiations are defined as a set of negotiation issues, options, compromises, utility functions and the level of resistance of the other negotiating party (Kersten and Noronha, 1999). Most part of DSS appeared in 1960s; they gained popularity since 1980. Many of such systems were designed for complex tasks of negotiations, such as identification of a conflict, management and decision, attempts to reach a consensus, assessment of the agreement, balance analysis (Kersten and Noronha, 1999). DSS assists a negotiator; it helps to assess the bids and offers, for example, to select a size of discount, to rate the offer, etc. The majority of such systems were generally intended for one user, a decision maker, and were applied in isolated computers or local networks. Some DSS are user-oriented, because they help users to understand and formalize their goals and preferences; other DSS are problem-oriented, because they help users to understand a problem's structure, to search for solutions and to make sensitivity analyses (Kersten and Lai, 2007a). Here, issues related to negotiations are solved using specific DS methodologies, such as the analytic hierarchy process (Saaty, 1980) or the conjoint analysis (Angur et al., 1996).

The need for specific negotiation DSS was realised as early as 1970 . Negotiation decision support systems (NDSS), in contrast to DSS, provide additional support for the negotiation process helping users to understand the priorities and limitations of the other negotiating party and to foresee their actions, suggesting possible coalitions and advising on selection and use of discounts. They are necessary for processes, which may demand a lot of time and which involve two or more persons, decision-makers. Since 1990, systems designed for negotiation support were already in full compliance with the NDSS definition (Bui et al., 2001; Kersten and Lai, 2007a), according to which a negotiation decision support system must have all capabilities of a DSS and must facilitate communication of negotiators (Lim and Benbasat, 1992). The communication support is necessary in order the DSS part of the system would not lose any data when negotiators are interacting and negotiating via computers (Holsapple et al., 1995). The main assumption behind NDSS is that the process of alternative decision-making supported by the system is achieved through a consensus (Kersten, 2003) and must become a contract. The main advantages of NDSS, according to Angur et al. (1996), are as follows: (a) increased likelihood to reach an agreement; (b) increased likelihood of achieving an efficient compromise solution; (c) faster negotiation process by achieving a suitable decision for all negotiating parties.

Whereas a joint decision-making process is often characteristic of a negotiation procedure, its analysis became part of research on group decision support systems (GDSS) (Nunamaker et al., 1987). The creation of DSS, some time latter, was followed by the creation of GDSS, which incorporated multi-criteria decision support models and offered group decision support for negotiations (Weistroffer et al., 2005). GDSS, which are used in negotiations, are very varied. There are systems which do not interfere with the decision-making process but only provide the information necessary for decision-making. Some systems take up the entire role of a decision-maker (Angur et al., 1996). When GDSS is used, an agreement is 
negotiated as a decision made by a group of agents. GDSS helps the agents by facilitating information exchange or mediating the agreement. Such systems model the joint editing process of numerous e-documents, which later make the contract (Schoop, 2004). Another typology of negotiation GDSS tries to express the utility function. Extension of GDSS means development of intergroup conflict negotiation systems.

As the number of web-based commercial transactions was growing rapidly, the interest in partial or full automation of negotiations soon became a relevant topic for research (Skylogiannis et al., 2007). The realisation that a separate class of special software is necessary for e-negotiations forced to supplement the group of already existing DSS, GDSS and NDSS, which assist persons in negotiations, with new types of software to facilitate and/or support negotiations and automate them: enegotiation table, negotiation agents and negotiation agents-assistants (Ströbel and Weinhardt, 2003, Kersten and Lai, 2007a).

E-negotiation table (ENT) is software that provides negotiators with a virtual space serving as a negotiation table and tools which can be used in negotiations, and only the negotiating parties have access to such virtual space and may post offers and messages (Rangaswamy and Shell, 1997; Ströbel and Weinhardt, 2003). This software facilitates certain activities in the internet, for example, search for partners, comparison of prices and determination of the value function. These tools may be independent of each other (users decide which and when should be used), but they must be mutually compatible and accessible to various users.

Two types of software systems, which successfully handled various aspects of automated negotiations, are based on the technology of software agents (Kraus, 1995). The aim of a negotiation software agent is to automate one or more negotiation actions or take over the en- tire negotiation (Jennings et al., 2001); the most important of their goals is to help negotiators in achieving the desired agreements. Such agents offer knowledge and information about the negotiating parties, the process and the problem; they take up the role of analysts and experts.

Other systems - negotiation agents-assistants - although based on the same models and technologies, were developed to provide reasonable and independent pieces of advice, criticism and support to one or more negotiating parties. Such agents are not directly involved in negotiations; instead they monitor the process and provide negotiators with information and knowledge about the problem, the process and/or other negotiating parties (Chen et al., 2005). The latter differ from NDSS by their autonomy and mobility, as well as by their ability to participate in negotiations partially. It is possible to design a negotiation software agent which assists only one negotiator and not all of them, thus giving such negotiator a competitive edge against the others (Kersten and Lai, 2007a).

Part of research on application of automated negotiation targets the negotiation strategy, which allows an agent (software) to take part in automated negotiations on behalf of a user (Jennings et al., 2001) and to apply different tactics (Cardoso et al., 1999). In automated negotiations, the negotiation strategy is a decision-making model used by the participants to achieve their goal under the negotiation protocol. The negotiation protocol is defined as a set of rules which limit an agent's actions. The tactics is creation of offers based on certain criteria. Strategies are derived in a formal way (Zlotkin and Rosenschein, 1996) or come from genetic algorithms (Tu et al., 2000). Another research area of automated negotiations is related to formal aspects of arguments and discussions (e.g. systems with agents which persuade and negotiate making arguments through linguistic exchange) (Parsons et al., 1998). In order to achieve a high level of inde- 
pendence, many systems of negotiation agents are based on artificial intelligence, such as case-base reasoning (Wong et al., 2000), planning (Sycara, 1990) or fuzzy logic (Kowalczyk and Bui, 2000).

The definition of E-negotiation systems (ENS) as a type of software used in webbased negotiations expands the description of negotiation software by adding any software which is able to help one or more negotiators. It includes communication systems used in negotiations (e.g. e-mail, chats and video conferences) (Moore et al., 1999; Lempereur, 2004), other types of software used for communication and facilitation of negotiations (Yuan et al., 2003), automated negotiations and auctions (Beam et al., 1999; Jennings et al., 2001) and software which combines negotiations and auction mechanisms (Teich et al., 2001). The concept of an e-negotiation system was suggested to embrace all these systems (Bichler et al., 2003; Ströbel and Weinhardt, 2003; Kersten and Lai, 2007a).

The more support ENS grants and the more actions the system performs independently, the more limited are the actions of a negotiator. The negotiation process model and negotiation protocol implemented in such ENS determine the limitations (Schoop, 2004; Kersten and Lai, 2007b). In order the negotiators get meaningful support, ENS must have mechanisms able to help its users to make "good" agreements efficiently (Ströbel, 2001). In such case the system must be based on a methodically reliable approach to negotiations (Goldman and Rojot, 2003), including use of the negotiation procedure model (Gulliver, 1979; Bichler et al., 2003; Kersten et al., 2004; Benyoucef and Rinderle, 2006).

Despite rather abundant scientific works on e-negotiation systems and automated decision support in negotiations, they describe only a few different NDSS suitable for negotiations in a construction process, namely WebNS (Yuan et al., 2003), Negoisst (Schoop et al.,
2003), electronic negotiation of government contracts (Paliwal et al., 2003), virtual real estate agent (Yen et al., 2000), e-negotiations through mutual services (Cheung et al., 2003) and framework for supply chain coordination in construction (Xue et al., 2005).

\section{VOICE STRESS ANALYSIS}

Systematic analysis of emotional effect on voice dates to 1960 , when it was noticed that the emotional state and voice expression are related (Scherer, 2003). In 2000, different specialists organised the international workshop "Voice and Emotions" to discuss these studies and various applied systems (technologies) used for speech and emotion recognition and derived from the studies (Douglas-Cowie et al., 2003). Increasing interest in recognition of emotions in voice is observed recently (Wallis et al., 2006).

Studies manly focus on incorporation of audiovisual communication types into interactive systems. For example, a system is able to determine user's emotional state from his/her facial expression or tone of the voice. These facts are also important in the area of real estate, because in some cases seller's emotional state is the direct reason of $\mathrm{RE}$ sales prices falling considerably below the average market price (McLean and Eldred, 2005). Moore (1996) summarised the hefty impact on speech caused by stress, i.e. internal and external stressors (e.g. cognitive strain, psychological stress and emotions, physiological limitations, physical and mechanical stressors).

Numerous emotion recognition studies analysed prosodic features of speech signals: emotional effect on pitch, intonation and the speed of speaking. In short, these studies proved the possibility to classify expression of the main emotions (joy, sadness, fear, anger, surprise and disgust) through speech with an accuracy of $74 \%$ using acoustic information only, and with an accuracy of $83 \%$ using both acoustic and linguistic information (Rigoll et al., 2005). 
Various systems with a broad variety of application possibilities exist; however, only a few of them can be deemed significant for construction and RE: Virtual Real-Estate Agent, which shows housing options to potential buyers in an RE agency's website, and Voice Stress Analysis (VSA) used in insurance (it could be adopted in $\mathrm{RE}$ insurance, in revisions of $\mathrm{RE}$ sales information and in RE negotiations). The Virtual Real-Estate Agent (Casell et al., 1999) is a talking animated character who introduces listed apartments and houses for sale to buyers who come to agency's website searching for a home to buy; this character is able to recognise a potential buyer's emotions (and the degree of interest in the displayed housing option) from the intonation or facial expression, and respectively adjusts its facial expression, tone and the time period allocated for a specific housing option. Insurance companies adopted the voice stress analysis in order to identify complaints and the cases of cheating in customer calls (Hays, 2003).

Voice stress analysers are based on simple technology. Voice analysis goes as follows: a conversation is recorded; then special software processes audio information and analyses speech frequencies. It has been established that muscles of human throat vibrate within the range between $8 \mathrm{~Hz}$ and $12 \mathrm{~Hz}$ due to the so-called microtremor discovered by Lippold (Lippold, 1971). It is claimed that when persons are excited or are under stress, as is often a case when a person is lying or does not know the answer to a question, their muscles, including vocal chords, as if get ready for the fight and vibrate at a frequency between $10 \mathrm{~Hz}$ and $12 \mathrm{~Hz}$, whereas calm and relaxed people speak within the range of $8 \mathrm{~Hz}$ and $9 \mathrm{~Hz}$ (Hopkins et al., 2005). Voice frequency increases when a person is not sure about his/her statement or tells lies and in cases of other stressful situations: cheating, misleading, anger, excitement, reluctance, etc. Some people experience more stress than others; it may also depend on the mood. Voice frequency changes and reveals to what extent a person perceives his/her statement as dangerous, risky and damaging in case the truth is revealed.

VSA devices record the presence of stress subject to deception (Haddad et al., 2002). VSA depends on three interrelated elements: electronic equipment (computer, application, telephone, microphone, audio record and processor), questioning technique and the researcher (Hopkins et al., 2005).

\section{WEB-BASED REAL ESTATE MULTIPLE CRITERIA NEGOTIATION DECISION SUPPORT SYSTEM}

The scientists of Vilnius Gediminas Technical University created Web-based Real Estate Multiple Criteria Negotiation Decision Support System (REMC-NDSS). Modules of alternative creation, multi-criteria analysis and negotiation are used by REMC-NDSS, which allow the users evaluating own needs and possibilities and understand importance of comprising, assisting in seeking for mutual benefit. REMC-NDSS can be found at the following web address: http://dss.vgtu.lt/ realestate/. The REMC-NDSS consists of a Decision Support Subsystem and Expert Subsystem. REMC-NDSS consists of a database, a database management system, model-base, a model-base management system and a user interface (see Figure 1).

Real estate listings are an interface for a seller to post listings. The system provides forms for sellers or real estate brokers to fill in information about their real estate. Real estate brokers wishing to present information on their objects must receive permission from REMC-NDSS administrator. Having this permission the broker inserts all the necessary information about real estate objects under sale in the REMC-NDSS databases according to the system's requirements (i.e. system of criteria, values and weights of criteria). Access 


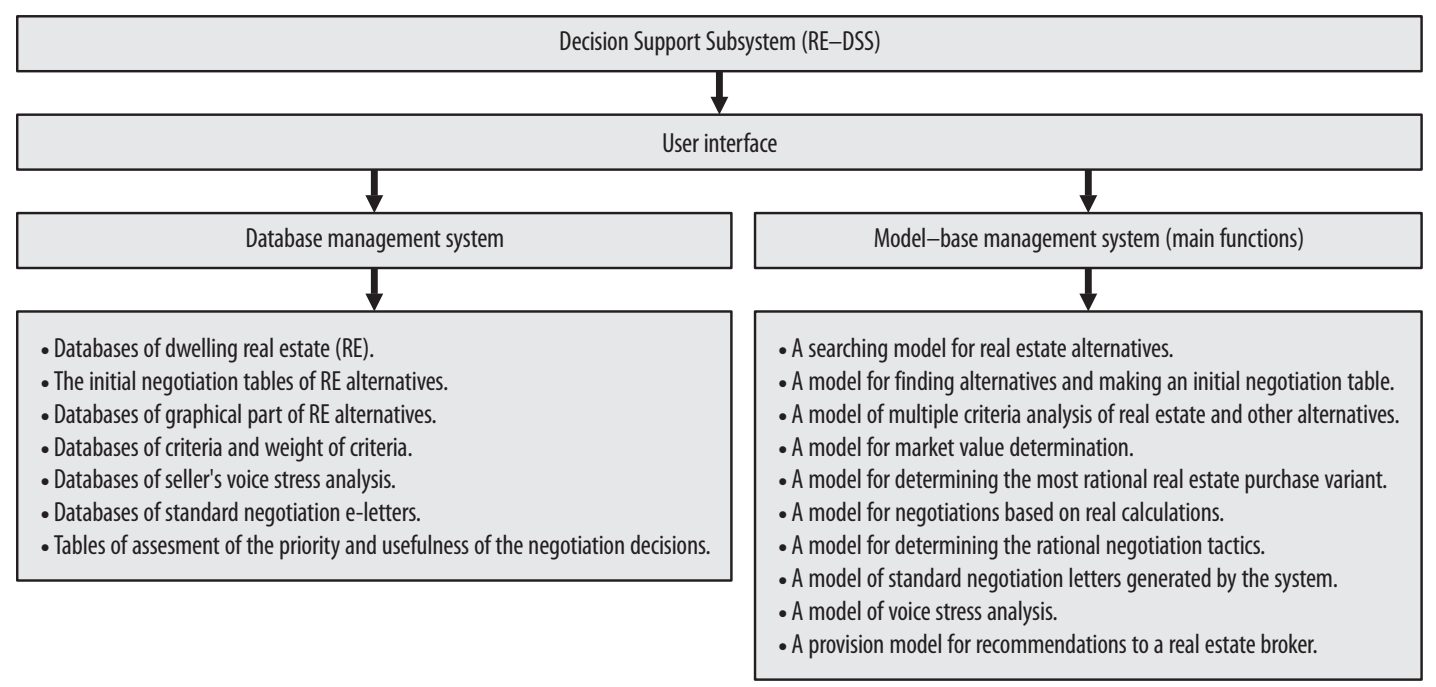

Figure 1. The components of Decision Support Subsystem

to the databases developed personally by brokers is provided only to the broker and to the REMC-NDSS administrator. At present the developed REMC-NDSS allows for the performance of the following five main functions: search for real estate alternatives; finding out alternatives and making an initial negotiation table; analysis of alternatives; negotiations; determination of the most rational real estate purchase variant. In order to throw more light on the REMC-NDSS, a more detailed description of some of the above-mentioned Subsystem functions follows. A consumer may perform a search for real estate alternatives from databases from different brokers. This is possible because the forms of data submissions are standardized at a specific level. Such standardization creates conditions that can be applied to special intelligent agents that are performing a search for the required real estate in various databases, and the gathering information/knowledge.

Consumers specify requirements and constraints and the system queries the information of a specific real estate from a number of online brokers. The system performs the tedious, time-consuming, and repetitive tasks of searching databases, retrieving and filtering information, and delivering it back to the user. Search results for a specific real estate are submitted in a textual, photo/video and graphical information on the real estate's alternatives and the initial negotiation table, which may include direct links to a Web page of brokers. When submitting such a display, the multiple criteria comparisons can become more effectively supported. By clicking the link "Expert and quantitative description of variants", the expert and quantitative description of private houses' alternatives is presented (see Figure 2). Each alternative described by the quantitative information (system of criteria, weights of criteria and values) has a number that coincides with the verbal and photographic information describing the mentioned alternative.

While going through the purchasing decision process a customer should examine a large number of alternatives, each of which is surrounded by a considerable amount of information/knowledge (economic, quality-architectural, aesthetic, comfort, infrastructure, technical, legal, technological), and other factors. Following on from the gathered information and knowledge, the multiple criteria analysis 
is then carried out. By using multiple criteria methods (Kaklauskas et al., 2007a, 2007b; Zavadskas et al., 2007, 2008b) as was developed by the authors, the buyer (broker) determines the initial priority, utility degree and market value of the analyzed real estate's alternatives. Clicking the link "Results of Multiple Criteria Evaluation" (see in the Figure 2), the results of the multiple criteria evaluation of the private house's alternatives are thus demonstrated (see Figure 3).

In the lower part of the obtained result's matrix the calculated significance of the real estate's alternatives, their priority and utility degree are presented (see Figure 3). The upper part of the obtained result's matrix shows the numbering of the real estate's alternatives (see Figure $3(l e f t))$. By clicking these underlined

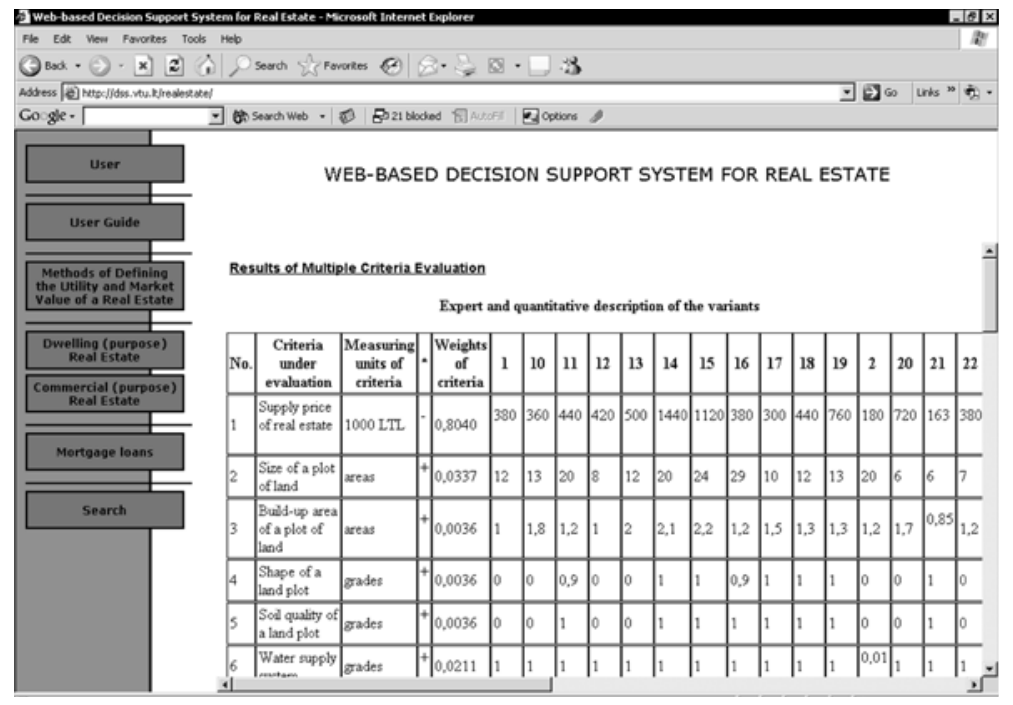

Figure 2. Expert and quantitative description of the real estate's alternatives (initial negotiation table)

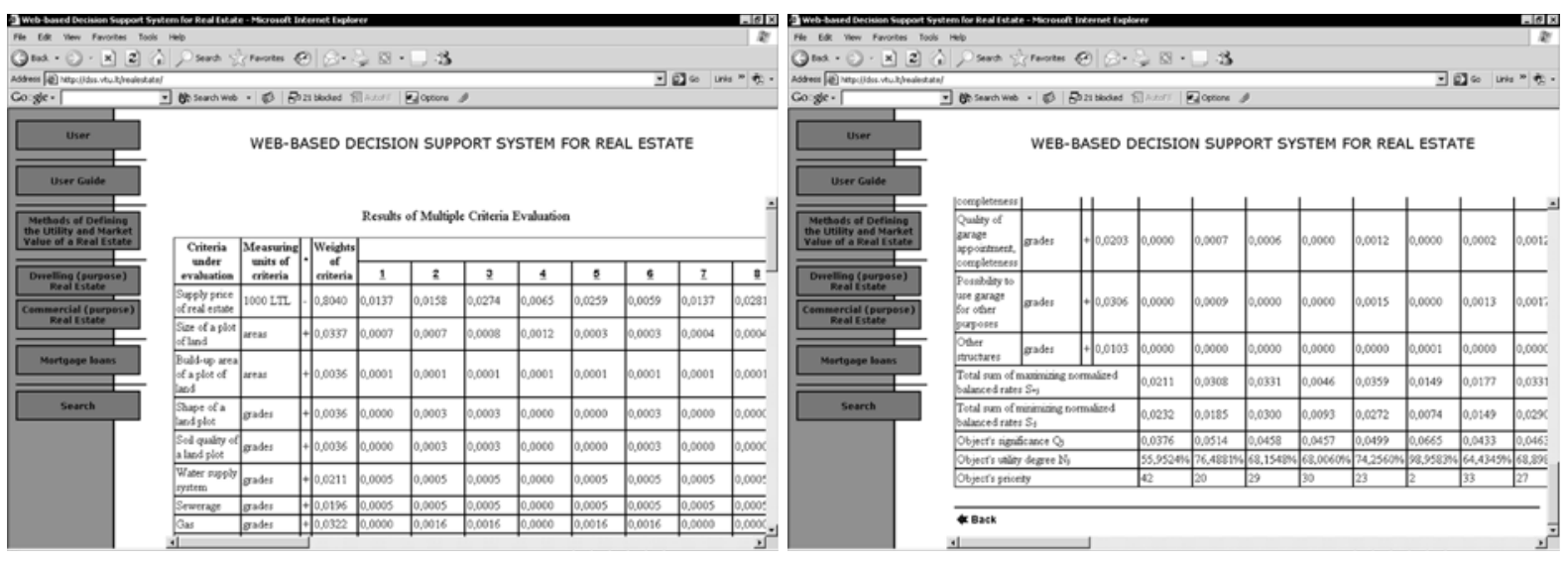

Figure 3. Results of multiple criteria evaluation of the private house's alternatives: upper part of the matrix for obtained results (left); lower part of the matrix for obtained results (right) 
numbers it is possible to calculate the market value of a certain alternative (see Figure 4). The table presented in Figure 4 (left) shows the iterations made during the calculation of the real estate's market value. The same information, only in graphical form is presented in Figure 4 (right). And by moving a mouse above any column of the graphical part, the numerical value of the column can be seen. For example, the market value of the eighth alternative was calculated by making 15 iterations (see Figure 4 (left)).

A buyer performing a multi-criteria analysis of all real estate alternatives selects the objects for starting the negotiations. For that purpose he/she marks (ticks a box with a mouse) the desirable negotiation objects (see Figure 5). A negotiations email are created by
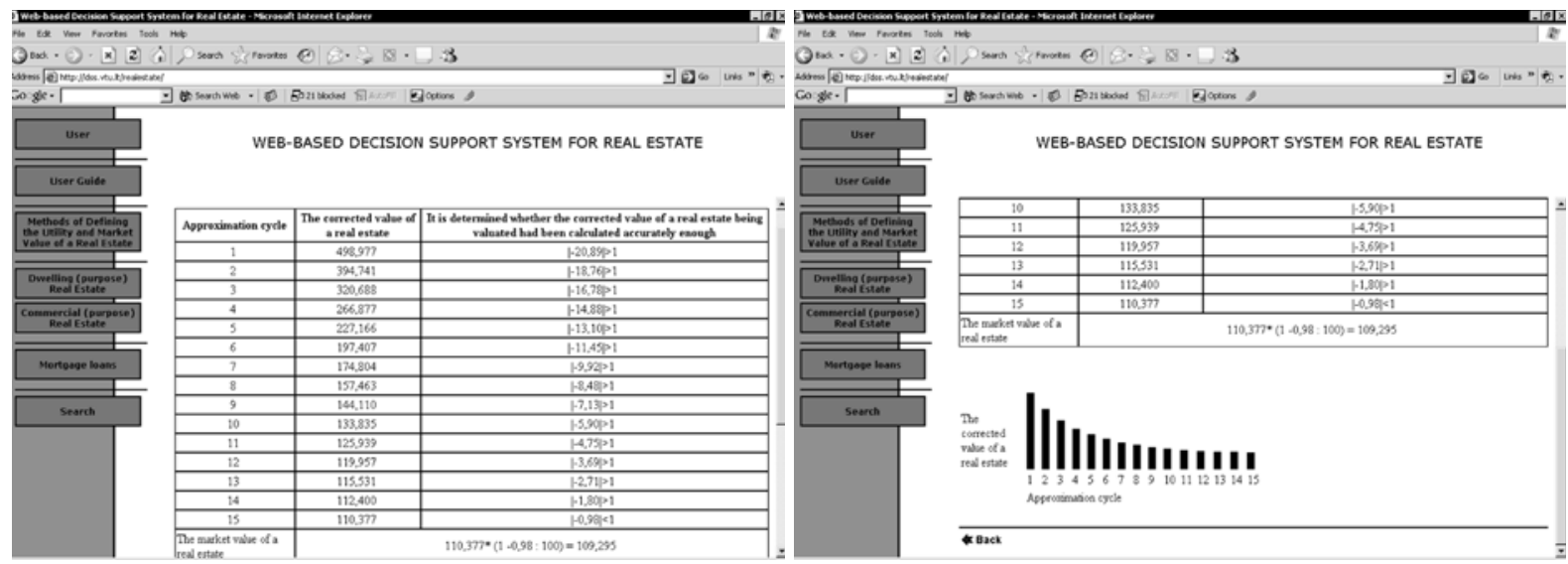

Figure 4. Calculation of the market value: presentation of the market value's calculations in numerical form (left); presentation of the market value's calculations in graphic form (right)

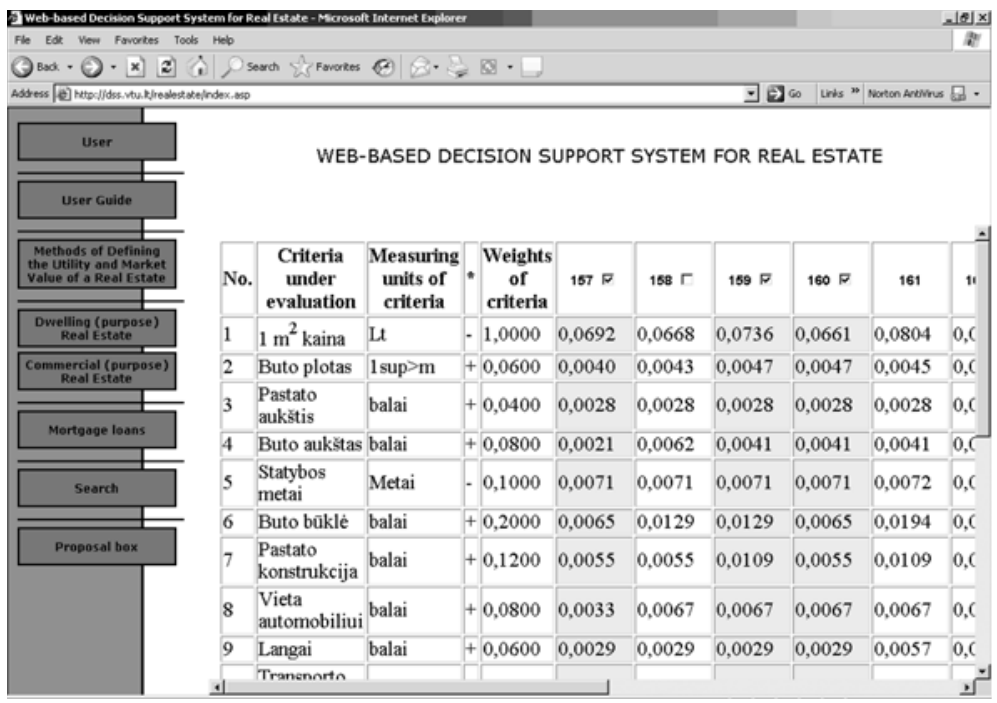

Figure 5. Selection of real estate objects for automated negotiations 
the Letter Writing Subsystem and sent to all real estate sellers after the selection of the desired objects is made and then Send is clicked.

During negotiations the buyer and the seller with the help of REMC-NDSS may perform real calculations (the utility degree, market value and purchase priorities) of the real estate. These calculations are performed on the basis of characteristics describing the real estate's alternatives obtained during negotiations (explicit and tacit criteria system, criteria values and weights). According to the results received, the final comparative table is then developed. Following on from the developed final comparative table the multiple criteria analysis and selection of the best real estate buying version is carried out by using REMC-NDSS.

There are two main categories of rules and procedures in the Expert Subsystem:

- Development of suggestions as to what brokers to use and for what reasons further negotiation should be carried out. With the help of the REMC-NDSS having determined the sequence of priority, the degree of utility and the market value of the real estate, the rules of the expert's subsystem suggests what brokers to use and for what reasons further negotiation should be carried out.

- Composition of comprehensively reasoned negotiation e-mail for each of the selected brokers. By using information inherited from the previous REMCNDSS calculations and predefined rules and procedures, the expert's subsystem composes of negotiation e-mail for each of the selected brokers, where it reasonably suggests that the price of the real estate should be decreased. The e-mail includes references to the calculations performed by REMC-NDSS.

\subsection{Case study}

The research performed by the authors included the following stages: voices of people selling their apartments were recorded in May-June and October-November of 2007, as well as in April-May of 2008, and then analysed. The sample included sellers of one-, two- and three-room apartments located in Antakalnis, Pilaitè and Žirmūnai districts of the city of Vilnius; their announcements about $\mathrm{RE}$ sales were listed in the advertiser newspaper Alio Reklama. Random announcements published in this newspaper were selected for the sample. A total of 152 voice recordings of people selling apartments were made and analysed; the specified floor area of their apartments was compared to the information available in the database of the Centre of Registers. The sellers were asked three main questions, and their answers were recorded:

1. What is the floor area?

2. What is the price?

3. Would you agree to bargain?

Figure 6 shows the data obtained from the analysis of conversation recordings, i.e. the voice frequency of a seller answering the question "What is the floor area?" and the delta $(\Delta)$ value expressed as a percentage, which is the difference between the area specified by the seller and the real area recorded in the database of the Centre of Registers.

Some real estate sellers did not lie and specified the real floor area, others exaggerated the area. The sellers added between 0.01 $\mathrm{m}^{2}$ and $6.8 \mathrm{~m}^{2}$ to the floor area, which corresponds to $0.01-7.97 \%$. Recordings of false answers show voice frequencies between $11.0 \mathrm{~Hz}$ and $11.5 \mathrm{~Hz}$. Recordings of people who specified correct floor area show voice frequencies between $10.4 \mathrm{~Hz}$ and $11.3 \mathrm{~Hz}$. Thus voice frequencies are slightly higher when persons lie about the floor area.

Figure 6 shows that voice frequencies of all people who exaggerated the floor area were higher than $11.0 \mathrm{~Hz}$. A trend can be observed 
that increasing deviation from the real area determines higher voice frequency. This fact is illustrated by the chart of variation trends of voice frequency and area difference shown in Figure 6.

The results obtained from the research on voice analysis are used in the Web-based Real Estate Multiple Criteria Negotiation Decision Support System (REMC-NDSS). Having searched for RE options, compared them and performed other related actions, an RE buyer can use voice analysis studies to select housing options for further negotiations. Buyers aware that a particular seller has lied about the floor area may choose a relevant negotiation strategy and tactics for further negotiations with such seller.

For example, someone wants to buy a tworoom apartment as soon as possible, because his wife is expecting. Currently, they rent a one-room apartment. They will buy RE for the first time. The buyer is already tired of the prolonged search for a suitable apartment; however, he got familiar with the situation in RE market within this period. The buyer is emotionally attached to Antakalnis because it is the district of his childhood. In Antakalnis (prestigious district), apartments are more expensive and the supply is lower compared to the amount of available options in new residential developments of the city of Vilnius. The

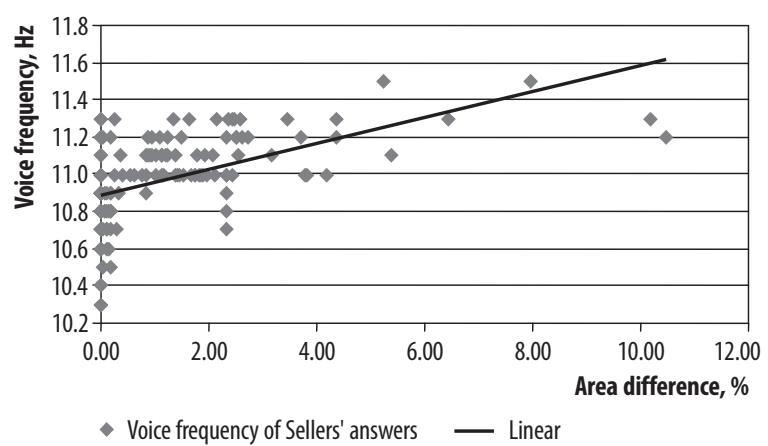

Figure 6. The chart which illustrates the trends of relation between voice frequency and area difference family can afford to pay LTL 400000 for RE at a maximum; LTL 350000 would be the best variant. The situation in the market changes, and the buyer worries that he might overpay for his future apartment.

The table of initial data for negotiations was prepared. More frequent alternatives/negotiation tactics used in real estate negotiations, such as "Go away", "An attractive alternative", "No more money" and others, were selected for real estate negotiations. The authors gave a more detailed description of these negotiation tactics in 2005 (see Kaklauskas and Urbanavičienè, 2005). Criteria describing the alternatives (in this case negotiation tactics) were selected, for example: "The offered sales price is the last possible price of buying", "Possibility for a buyer to contact the seller later", "The buyer tells an agent or a seller he has seen a similar house and is very interested in this new option"..."Required time period", "Nervous strain"... and "The necessary level of buyer's negotiation skills". The criteria were ranked on a scale of 1 to 9 ( 1 - least important, 9 - most important), and the weight of each criterion was established. The created Webbased Real Estate Multiple Criteria Negotiation Decision Support System (REMC-NDSS) considers each negotiation tactics, generates relevant negotiating e-mails and sends to RE sellers selected by the buyer for negotiations.

Following on the developed final comparative table the multiple criteria analysis and selection of the best real estate negotiation tactic are being carried out using REMC-NDSS (see Figure $7 \mathrm{a}$ and b).

In this case, the created REMC-NDSS shows that the tactics "Would you sell for ..... LTL?" has the priority and the buyer might use it in order to negotiate a better price for real estate. The second tactics recommended by the system is "An attractive alternative" tactics. The results of seller's voice stress analysis showed that the seller was lying. He claimed his apartment to be bigger than it really was. 


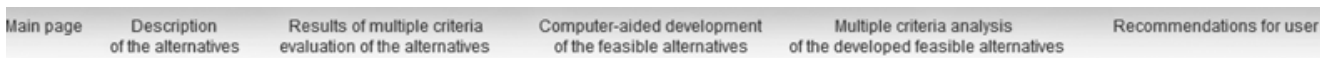

\section{Multiple criteria analysis of the developed feasible alternatives}

\begin{tabular}{|c|c|c|c|c|c|c|c|c|c|c|c|}
\hline \multicolumn{12}{|c|}{ Quantitative and qualitative information pertinent to alternatives } \\
\hline \multirow[t]{2}{*}{ Criteria describing the alternatives } & \multirow{2}{*}{\multicolumn{2}{|c|}{$\begin{array}{l}\text { Measuring } \\
\text { units }\end{array}$}} & \multirow[t]{2}{*}{ Weight } & \multicolumn{8}{|c|}{ Compared alternatives } \\
\hline & & & & $\frac{\text { Go away }}{\text { tactic }}$ & $\begin{array}{l}\text { An attractive } \\
\text { alternative: } \\
\text { tactic }\end{array}$ & $\begin{array}{l}\text { The } \\
\text { comparative } \\
\text { value" tactic" }\end{array}$ & $\begin{array}{l}\text { The third } \\
\text { party } \\
\text { tactic } \\
\end{array}$ & \begin{tabular}{|l} 
No more \\
money \\
tactic \\
\end{tabular} & $\begin{array}{l}\text { Wold you } \\
\text { sell for...? } \\
\text { tactic }\end{array}$ & $\frac{\text { Stall and }}{\text { jolt tactic }}$ & $\begin{array}{l}\text { Unexpected } \\
\text { auction tactic }\end{array}$ \\
\hline $\begin{array}{l}\text { The offered sales price is the last possible } \\
\text { price of buying }\end{array}$ & + & Points & 0,14 & 0,027391 & 0,021304 & 0,015217 & 0,015217 & 0,024348 & 0,021304 & 0,006087 & 0,00913 \\
\hline $\begin{array}{l}\text { Possibility for a buyer to contact the seller } \\
\text { later because of "curiosity" or "just to ask" }\end{array}$ & + & Points & 0,28 & 0,07 & 0,054444 & 0,038889 & 0,038889 & 0,054444 & 0,007778 & 0,007778 & 0,007778 \\
\hline $\begin{array}{l}\text { The buyer tells an agent or a seller he has } \\
\text { seen a similar house and is very interested } \\
\text { in this new option }\end{array}$ & + & Points & 0,13 & 0,026 & 0,033429 & 0,026 & 0,022286 & 0,003714 & 0,011143 & 0,003714 & 0,003714 \\
\hline $\begin{array}{l}\text { Husband's perspective on the value and } \\
\text { quality ratio }\end{array}$ & + & Points & 0,18 & 0,026471 & 0,037059 & 0,047647 & 0,015882 & 0,005294 & 0,015882 & 0,026471 & 0,005294 \\
\hline $\begin{array}{l}\text { Wife's perspective on the value and quality } \\
\text { ratio }\end{array}$ & + & Points & 0,17 & 0,027674 & 0,031628 & 0,027674 & 0,035581 & 0,01186 & 0,01186 & 0,019767 & 0,003953 \\
\hline The buyer cannot afford a higher price & + & Points & 0,23 & 0,04 & 0,035 & 0,035 & 0,005 & 0,045 & 0,04 & 0,025 & 0,005 \\
\hline $\begin{array}{l}\text { Buyer asks the seller directly bypassing the } \\
\text { RE agent: "What is the possible lowest price } \\
\text { you would take?" }\end{array}$ & + & Points & 0,28 & 0,041702 & 0,04766 & 0,041702 & 0,029787 & 0,041702 & 0,053617 & 0,017872 & 0,005957 \\
\hline $\begin{array}{l}\text { Buyer retreats to "think over" the new sales } \\
\text { price hinting that he probably would agree to } \\
\text { buy at such price }\end{array}$ & + & Points & 0,24 & 0,02 & 0,033333 & 0,033333 & 0,053333 & 0,006667 & 0,026667 & 0,06 & 0,006667 \\
\hline $\begin{array}{l}\text { At the next meeting, the buyer rejects the } \\
\text { offered price and drags the negotiations } \\
\text { waiting for discounts from the other party. }\end{array}$ & + & Points & 0,14 & 0,026667 & 0,026667 & 0,006667 & 0,026667 & 0,01 & 0,01 & 0,03 & 0,003333 \\
\hline $\begin{array}{l}\text { Unexpected auction of property sales (it } \\
\text { usually happens in the so-called seller } \\
\text { markets when the number of buyers } \\
\text { exceeds the number of sellers) }\end{array}$ & + & Points & 0,19 & 0,052414 & 0,006552 & 0,006552 & 0,006552 & 0,006552 & 0,045862 & 0,006552 & 0,058966 \\
\hline
\end{tabular}

\begin{tabular}{|c|c|c|c|c|c|c|c|c|c|c|}
\hline $\begin{array}{l}\text { Husband's perspective on the value and } \\
\text { quality ratio }\end{array}$ & + Points & 0,18 & 0,026471 & 0,037059 & 0,047647 & 0,015882 & 0,005294 & 0,015882 & 0,026471 & 0,005294 \\
\hline $\begin{array}{l}\text { Wife's perspective on the value and quality } \\
\text { ratio }\end{array}$ & + Points & 0,17 & 0,027674 & 0,031628 & 0,027674 & 0,035581 & 0,01186 & 0,01186 & 0,019767 & 0,003953 \\
\hline The buyer cannot afford a higher price & + Points & 0,23 & 0,04 & 0,035 & 0,035 & 0,005 & 0,045 & 0,04 & 0,025 & 0,005 \\
\hline $\begin{array}{l}\text { Buyer asks the seller directly bypassing the } \\
\text { RE agent: "What is the possible lowest price } \\
\text { you would take? }\end{array}$ & + Points & 0,28 & 0,041702 & 0,04766 & 0,041702 & 0,029787 & 0,041702 & 0,053617 & 0,017872 & 0,005957 \\
\hline $\begin{array}{l}\text { Buyer retreats to "think over" the new sales } \\
\text { price hinting that he probably would agree to } \\
\text { buy at such price }\end{array}$ & + Points & 0,24 & 0,02 & 0,033333 & 0,033333 & 0,053333 & 0,006667 & 0,026667 & 0,06 & 0,006667 \\
\hline $\begin{array}{l}\text { At the next meeting, the buyer rejects the } \\
\text { offered price and drags the negotiations } \\
\text { waiting for discounts from the other party. }\end{array}$ & + Points & 0,14 & 0,026667 & 0,026667 & 0,006667 & 0,026667 & 0,01 & 0,01 & 0,03 & 0,003333 \\
\hline $\begin{array}{l}\text { Unexpected auction of property sales (it } \\
\text { usually happens in the so-called seller } \\
\text { markets when the number of buyers } \\
\text { exceeds the number of sellers) }\end{array}$ & + Points & 0,19 & 0,052414 & 0,006552 & 0,006552 & 0,006552 & 0,006552 & 0,045862 & 0,006552 & 0,058966 \\
\hline Required period & Foints & 1 & 0,076923 & 0,076923 & 0,076923 & 0,269231 & 0,076923 & 0,038462 & 0,346154 & 0,038462 \\
\hline Nervous strain & Foints & 0,88 & 0,193171 & 0,042927 & 0,085854 & 0,085854 & 0,107317 & 0,042927 & 0,193171 & 0,12878 \\
\hline The amount of information a buyer needs & Foints & 0,45 & 0,047368 & 0,071053 & 0,071053 & 0,047368 & 0,039474 & 0,039474 & 0,071053 & 0,063158 \\
\hline Reliability of information & Foints & 0,42 & 0,031698 & 0,071321 & 0,071321 & 0,039623 & 0,031698 & 0,031698 & 0,071321 & 0,071321 \\
\hline $\begin{array}{l}\text { Fear that someone else might buy the } \\
\text { selected apartment }\end{array}$ & - Points & 0,72 & 0,135 & 0,06 & 0,075 & 0,075 & 0,105 & 0,06 & 0,075 & 0,135 \\
\hline Fear that the price might increase/decrease & Foints & 1 & 0,195652 & 0,086957 & 0,108696 & 0,108696 & 0,152174 & 0,086957 & 0,108696 & 0,152174 \\
\hline $\begin{array}{l}\text { Fatigue caused by prolonged search for } \\
\text { suitable housing }\end{array}$ & - Points & 0,23 & 0,017692 & 0,017692 & 0,017692 & 0,061923 & 0,017692 & 0,008846 & 0,079615 & 0,008846 \\
\hline The amount of experience a buyer needs & Points & 0,43 & 0,067895 & 0,030175 & 0,052807 & 0,045263 & 0,052807 & 0,045263 & 0,067895 & 0,067895 \\
\hline $\begin{array}{l}\text { The necessary level of buyer's negotiation } \\
\text { skills }\end{array}$ & Points & 0,38 & 0,065769 & 0,029231 & 0,036538 & 0,043846 & 0,043846 & 0,051154 & 0,065769 & 0,043846 \\
\hline Voice analysis & + Points & 0,45 & 0,059434 & 0,067925 & 0,076415 & 0,059434 & 0,033962 & 0,067925 & 0,059434 & 0,025472 \\
\hline \multicolumn{3}{|c|}{$\begin{array}{l}\text { The sums of weighted normalized maximizing (projects 'pluses') } \\
\text { indices of the alternative }\end{array}$} & 0,4178 & 0,395 & 0,3551 & 0,3086 & 0,2435 & 0,312 & 0,2627 & 0,1353 \\
\hline \multicolumn{3}{|c|}{$\begin{array}{l}\text { The sums of weighted normalized minimizing (projects 'minuses') } \\
\text { indices of the alternative }\end{array}$} & 0,8312 & 0,4863 & 0,5959 & 0,7768 & 0,6269 & 0,4048 & 1,0787 & 0,7095 \\
\hline \multicolumn{3}{|l|}{ Significance of the alternative } & 1,0514 & 1,2532 & 1,0332 & 0,8571 & 0,914 & 1,2829 & 0,6655 & 0,7504 \\
\hline \multicolumn{3}{|l|}{ Priority of the alternative } & 3 & 2 & 4 & 6 & 5 & 1 & 8 & 7 \\
\hline \multicolumn{3}{|l|}{ Utility degree of the alternative (\%) } & $81,96 \%$ & $97,69 \%$ & $80,54 \%$ & $66,81 \%$ & $71,25 \%$ & $100 \%$ & $51,88 \%$ & $58,49 \%$ \\
\hline
\end{tabular}

Figure 7. Fragments of multiple criteria analysis of the feasible alternatives (negotiation tactics): a) - top part of the table and b) - bottom part of the table 
It was checked with the real floor area of this apartment recorded in the database of the Centre of Registers. The difference between the real and the claimed floor area was $3 \%$. The buyer successfully applied the tactics recommended by the system (e-mails prepared by the system for each negotiation tactics) and bargained $4 \%$ off the initially specified real estate price.

\section{CONCLUSIONS}

To improve efficiency of negotiations on terms of Real Estate Sales and Purchase Agreement, the Web-based Negotiation Decision Support System for Real Estate was developed based on the multiple criteria analysis model for real estate negotiations and the analysis of electronic negotiation decision support systems.

Created Web-based Real Estate Multiple Criteria Negotiation Decision Support System (REMC-NDSS) performs the following functions:

- Search for alternatives by the use of standardized data presentation forms.

- Finding out alternatives and making initial comparative tables. Consumers specify requirements and constraints and the System queries the information of specific real estate from a number of online brokers. The System performs the tedious, time-consuming, and repetitive tasks of searching databases, retrieving and filtering information and delivering the information back to the user. Results of a search of specific real estate are submitted in initial comparative table. By submission such a display, the multiple criteria comparisons can become more effectively supported.

- Multiple criteria analysis of alternatives. While going through the purchasing decision process a consumer must examine a large number of alternatives, each of which is surrounded by a considerable amount of information (economic, quality, technical, legal, and other factors). Following on from the gathered information the priority and utility degree of alternatives is then calculated. During this analysis the buyer (broker) determines the initial priority, utility degree and market value of the analysed real estate alternatives.

- Negotiations based on real calculations. During on-line-negotiations the buyer (seller) with the help of REMC-NDSS may perform real calculations. According to the results received the final comparative table is developed.

- Determination of the most rational real estate purchase variant on the ground of characteristics describing effectiveness of the analysed alternatives (priority, utility degree and market value). Following on the developed final comparative table the multiple criteria analysis and selection of the best real estate buying version are being carried out using REMC-NDSS.

- Search for alternatives by the use of standardized data presentation forms.

- Presentation of recommendations. On this stage the system can offer to increase or reduce the price of an object being sold with consideration of object's popularity (this is set having assessed interest of users in object's system).

- The research included analysis of changing voice frequencies of real estate sellers and comparison of the frequencies with the difference between the claimed area of apartment for sale and the real area recorded in the Real Estate Register; a trend was noticed that increasing difference (bigger lie) determines increasing voice frequency. Therefore, voice stress analysis was applied in real estate negotiations to enable better assumptions about the other negotiating party and to select efficient negotiation tactics. 
- Using the e-mail function and the templates of negotiating e-mails generated by the system for each negotiation tactics, negotiators are able to provide extensive reasoning of their position.

Considering that this system is adjusted for assessment of various alternatives and determination of rational option, it can be successfully applied seeking to set efficient RE negotiation process.

The created REMC-NDSS system can be applied in practical implementation of negotiations in virtual environment.

\section{REFERENCES}

Agrawal, M. K. and Chari, K. (2009) Learning negotiation support systems in competitive negotiations: A study of negotiation behaviors and system impacts, International Journal of Intelligent Information Technologies, 5(1), pp. 1-23.

Angur, M.G., Loft, V. and Sarkis, J. (1996) A hybrid conjoint measurement and bi-criteria model for a two group negotiation problem, Socio-Economic Planning Sciences, 30(3), pp. 195-206.

Antuchevičienè, J., Turskis, Z. and Zavadskas, E.K. (2006) Modelling renewal of construction objects applying methods of the game theory, Technological and Economic Development of Economy, 12(4), pp. 263-268.

Beam, C., Segev, A., Bichler, M. and Krishnan, R. (1999) On negotiations and deal making in electronic markets, Information Systems Frontier, 1(3), pp. 241-258.

Benyoucef, M. and Rinderle, S. (2006) Modeling e-negotiation processes for a service oriented architecture, Group Decision and Negotiation, 15(5), pp. 449-467.

Bichler, M., Kersten, G.E. and Strecker, S. (2003) Towards a structured design of electronic negotiations, Group Decision and Negotiation, 12(4), pp. 311-335.

Brown, B. (2005) Choice and mobility: decision making on the move, pp. 1-15. [Online] Available at: http://www.socialsciences.manchester.ac.uk/ disciplines/sociology/about/events/ethnography/ past/documents/choice-and-mobility.pdf [accessed 27 September 2008]

Brzeski, W.J. (2005) The role and prospects of real estate brokerage. In: Proceedings of Real Estate
Conference on Real Estate, Vilnius, Lithuania, 25-27 January 2005.

Bui, T.X., Yen, J., Hu, J. and Sankaran, S. (2001) A Multi-attribute negotiation support system with market signaling for electronic markets, Group Decision and Negotiation, 10(6), pp. $515-537$.

Cardoso, H., Schafer, M. and Oliveira, E., (1999) A Multi-agent system for electronic commerce including adaptive strategic behaviours. In: Proceedings of the 9th Portuguese Conference on Artificial Intelligence: Progress in Artificial Intelligence, pp. 252-266.

Casell, J., Bickmore, T., Billinghurst, M., Campbell, L., Chang, K., Vilhjalmsson, H. and Yan, H. (1999) Embodiment in conversational interfaces: REA, In: Proceedings of the CHI'99 Conference, Pitsburg, PA, pp. 520-527.

Chen, E., Vahidov R. and Kersten, G.E. (2005) Agent-supported negotiations in the e-marketplace, International Journal of Electronic Business, 3(1), pp. 28-49.

Cheung, S.C., Hung, P.C.K. and Chiu, D.K.W. (2003) On the e-negotiation of unmatched logrolling views. In: Proceedings of the 36th Hawaii International Conference on System Sciences (HICSS'03), http://doi.ieeecomputersociety.org/10.1109/HICSS.2003.1173687

Chiu, D.K.W., Cheung, S.C., Hung, P.C.K., Chiu, S.Y. and Chung, A.K. (2005) Developing e-negotiation support with a meta-modeling approach in a web services environment, Decision Support Systems, 40(1), pp. 51-69.

Clemen, R. (1996) Making hard decisions: An introduction to decision analysis. North Scituate (MA): Duxbury Press.

Crowston, K. and Myers, M.D. (2004) Information technology and the transformation of industries: three research perspectives, Journal of Strategic Information Systems, 13(1), pp. 5-28.

Douglas-Cowie, E., Cowie, R. and Campbell, N. (2003) Speech and emotion, Speech Communication, 40(1-2), pp. 1-3.

Ehtamo, H., Hämäläinen, R.P. and Koskinen, V. (2004) An e-learning module on negotiation analysis. In: Proceedings of the 37th Hawaii International Conference on System Sciences, pp. 1-9.

Figueira, J., Greco, S. and Ehrgott, M. (eds.) (2005) Introduction. In: Multiple Criteria Decision Analysis: State of the Art Surveys, Springer Science + Business Media, Inc. Boston eBook. 
Goldman, A. and Rojot, J. (2003) Negotiation. Theory and practice. Kluwer, The Hague.

Gulliver, P.H., (1979) Disputes and negotiations: A cross-cultural perspective. Orlando, FL: Academic Press.

Haddad, D., Walter, S., Ratley, R. and Smith, M. (2002) Investigation and evaluation of voice stress analysis technology (final report). Technical Report, US Department of Justice (document No.: 193832).

Hays, D. (2003) Voice stress analysis: New tool in insurers' fraud arsenal. National underwriter. Property and Casuality-Risk and Benefits Management. [Online] High Beam Research. Available at: http://www.highbeam.com/ doc/1G1-109907791.html [accessed 2 October 2008]

Holsapple, C., Lai, H. and Whinston, A. (1995) Analysis of negotiation support system research, Journal of Computer Information Systems, 35(3), pp. 2-11.

Hopkins, C.S., Benincasa, D.S., Ratley, R.J. and Grieco, J.J. (2005) Evaluation of voice stress analysis technology. Proceedings of the $38^{\text {th }}$ Hawaii International Conference on System Sciences, pp. 1-10.

Jennings, N.R., Faratin, P., Lomuscio, A.R., Parsons, S., Sierra, C. and Wooldridge, M. (2001) Automated negotiations: Prospects, methods and challenges, Group Decision and Negotiation, 10(2), pp. 199-215.

Kaklauskas, A. and Urbanavičienė, V. (2005) Intelektualus miestas ir internetinè nekilnojamojo turto daugiakriterinè derybinè sprendimu paramos sistema [Intellcity and web-based multi criteria negotiation decision support system], Technological and Economic Development of Economy, 11(3), pp. 183-189. (In Lithuanian)

Kaklauskas, A., Zavadskas, E.K. and Trinkūnas, V. (2007a) A multiple criteria decision support on-line system for construction, Engineering Applications of Artificial Intelligence, 20(2), pp. $163-175$.

Kaklauskas, A., Zavadskas, E.K., Banaitis, A. and Šatkauskas, G. (2007b) Defining the utility and market value of real estate: A multiple criteria approach, International Journal of Strategic Property Management, 11(2), pp. 107-120.

Keeney, R.L. and Raiffa, H. (1993) Decision with multiple objectives: Preference and value tradeoffs. New York: Cambridge University Press.
Kersten, G.E. and Lai, H. (2007a) Negotiation support and e-negotiation systems: An overview, Group Decision and Negotiation, 16(6), pp. 553-586.

Kersten, G.E. and Lai, H. (2007b) Satisfiability and completeness of protocols for electronic negotiations, European Journal of Operational Research, 180(2), pp. 922-937.

Kersten, G.E. (2003) The science and engineering of e-negotiation: An introduction. In: Proceedings of the $36^{\text {th }}$ annual Hawaii international conference on system sciences, IEEE, pp. 27-36.

Kersten, G.E. and Noronha, S.J. (1999) WWWbased negotiation support: Design, implementation, and use, Decision Support Systems, 25(2), pp. 135-154.

Kersten, G.E., Law, K.P. and Strecker, S. (2004) A software platform for multiprotocol e-negotiations. InterNeg Research Papers 04/04. [Online] InterNeg, Available at: http://interneg. concordia.ca/interneg/research/papers/2004/04. pdf [accessed 5 May 2008].

Keršulienè, V. and Urbanavičienè, V. (2007) Selection of economy based methods for resolution of disputes originated between the client and contractor. In: Proceedings of the 9th International Conference "Modern building materials, structures and techniques", Vilnius Gediminas Technical University, Vilnius: Technika, pp. 287-292.

Kim, J.B., Kersten, G.E., Law, K.P. and Strecker, S. (2007) E-negotiation system development: Using negotiation protocols to manage software components, Group Decision and Negotiation, 16(4), pp. 321-334.

Kowalczyk, R. and Bui, V. (2000) On fuzzy e-negotiation agents: Autonomous negotiation with incomplete and imprecise information. In: Proceedings of the 11th International Workshop on Database and Expert Systems Applications, 2000 IEEE, Computer Society Washington, DC, USA, pp. 1034-1038.

Kraus, S. (1995) Multiagent negotiation under time constraints, Journal of Artificial Intelligence Research, 75(2), pp. 297-345.

Lempereur, A. (2004) Innovation in teaching negotiation: Towards a relevant use of multimedia tools, International Negotiation, 9(1), pp. 141-160.

Lim, L.H. and Benbasat, I. (1992) A theoretical perspective of negotiation support systems, Journal of Management Information Systems, 9(3), pp. 27-44. 
Lippold, O. (1971) Psychological tremor, Scientific American, 224(3), pp. 65-73.

McLean, A. and Eldred, G.W. (2005) Investing in real estate. $5^{\text {th }}$ ed., John Wiley and Sons.

Meszek, W. (2008) The analysis of property value increase as a result of infrastructural investment projects, International Journal of Environment and Pollution, 35(2/3/4), pp. 345-365.

Moore, D.A., Kurtzberg, T.R., Thompson, L.L. and Morris, M.W. (1999) Long and short routes to success in electronically mediated negotiations: Group affiliations and good vibrations, Organizational Behavior and Human Decision Processes, 77(1), pp. 22-43.

Moore, R.K. (1996) Editorial, Speech Communication, 20(1-2), pp. 1-2.

Murtoaro, J. and Kujala, J. (2007) Project negotiation analysis, International Journal of Project Management, 25(7), pp. 722-733.

Neale, M.A. and Bazerman, M.H. (1991) Cognition and rationality in negotiation. New York: Free Press.

Nunamaker, J., Applegate, L. and Konsynski, B. (1987) Facilitating group creativity: Experience with a group decision support system, Journal of Management Information Systems, 3(4), pp. 5-19.

Paliwal, A., Adam, N., Atluri, V. and Yesha, Y. (2003) Electronic negotiation of government contracts trough transducers. In: Proceedings of the 2003 annual national conference on Digital government research, Boston, MA: ACM International Conference Proceeding Series, 130, pp. 1-6.

Parsons, S., Sierra, Ch. and Jennings, N. (1998) Agents that reason and negotiate by arguing, Journal of Logic Computation, 8(3), pp. 261292.

Pearce, D.W. (ed.) (2006) Aiškinamasis ekonomikos anglų-lietuvių kalbu žodynas [Explanatory English-Lithuanian dictionary of economics], Vilnius: TEV. (In Lithuanian)

Peldschus, F. (2005) Multiple-criteria analysis in the construction of motorways, Technological and Economic Development of Economy, 11(1), pp. 32-35.

Peldschus, F. (2009) Experience of the game theory application in construction management, Technological and Economic Development of Economy, 14(4), pp. 531-545.
Pruitt, D.G. (1995) Process and outcome in community mediation, Negotiation Journal, 11(4), pp. 365-377.

Raiffa, H. (1982) The art and science of negotiation. Cambridge, MA: Harvard University Press.

Raiffa, H., Richardson, J. and Metcalfe, D. (2002) Negotiation analysis: The science and art of collaborative decision-making. Cambridge: Harvard University Press.

Rangaswamy, A. and Shell, G. (1997) Using computers to realize joint gains in negotiations: Toward an "electronic bargaining table", Management Science, 43(8), pp. 1147-1163.

Rigoll, G., Muller, R. and Schuller, B. (2005) Speech emotion recognition exploiting acoustic and linguistic information sources. In: Proceedings SPECOM, Patras, Greece, pp. 61-67.

Saaty, T.L. (1980) The Analytic Hierarchy Process. New York: McFGraw-Hill.

Scherer, K.R. (2003) Vocal communication of emotion: A review of research paradigms, Speech Communication, 40(1-2), pp. 227-256.

Schoop, M. (2004) The worlds of negotiation. In: Aakhus, M. and Lind, M. (eds.), Proceedings of the 9th International Working Conference on the Language-Action Perspective on Communication Modelling (LAP 2004), New Brunswick, New Jersey, USA, pp. 179-196.

Schoop, M., Jertila, A. and List, T. (2003) Negoisst A negotiation support system for business-tobusiness electronic commerce, Data Knowledge and Engineering, 47(3), pp. 371-401.

Sebenius, J. (2002) International negotiation analysis. In: Kremenyuk, V. (ed.), International Negotiation: Analysis, Approaches, Issues. California: Jossey-Bass.

Skylogiannis, T., Antoniou, G., Bassiliades, N., Governatori, G. and Bikakis, A. (2007) DR-NEGOTIATE - A system for automated agent, Data Knowledge and Engineering, 63(2), pp. 362380.

Ströbel, M. (2000) On auctions as the negotiation paradigm of electronic markets, Electronic Markets, 10(1), pp. 39-44.

Ströbel, M. and Weinhardt, C. (2003) The Montreal Taxonomy for electronic negotiations, Group Decision and Negotiation, 12(2), pp. 143-164.

Ströbel, M. (2001) Design of roles and protocols for electronic negotiations, Electronic Commerce Research Journal, 1(3), pp. 335-353. 
Sycara, K. (1990) Negotiation planning: An AI approach, European Journal of Operational Research, 46(2), pp. 216-234.

Teich, J., Wallenius, H., Wallenius, J. and Zaitsev, A. (2001) Designing electronic auctions: An internet-based hybrid procedure combining, Electronic Commerce Research, 1(3), pp. 301-314.

Tu, M.T., Wolff, E. and Lamersdorf, W. (2000) Genetic algorithms for automated negotiations: A FSM-based application approach. In: Proceedings of the 11th International Workshop on Database and Expert Systems Applications, IEEE Computer Society, Washington, DC, USA, pp. 1028-1033.

Turel, O. and Yuan, Y. (2008) You can't shake hands with clenched fists: Potential effects of trust assessments on the adoption of e-negotiation services, Group Decision and Negotiation, 17(2), pp. 141-155.

Turskis, Z., Zavadskas, E.K. and Peldschus, F. (2009) Multi-criteria optimization system for decision making in construction design and management, Engineering Economics, 1(61), pp. 7-17.

Urbanavičienè, V., Kaklauskas, A. and Zavadskas, E.K. (2009) The conceptual model of construction and real estate negotiation, International Journal of Strategic Property Management, 13(1), pp. 53-70.

Vetschera, R. (2007) Preference structures and negotiator behavior in electronic negotiations, Decision Support Systems, 44(1), pp. 135-146.

Vetschera, R., Kersten, G.E. and Koeszegi, S. (2006) The determinants of NSS success: An integrated model and its evaluation, Journal of Organizational Computing and Electronic Commerce, 16(2), pp. 123-148.

Von Neumann, J. and Morgenstern, O. (1944) Theory of Games and economic behaviour. Princeton University Press.

Wallis, P., Moore, R., Fagerberg, P., Cavazza, M. and Wilks, Y. (2006) Emotion in human-agent interfaces. [Online] COMPANIONS consortium: State of the art papers. Available at: http:// www.companions-project.org/downloads/Companions_SoA3_Emotion.pdf [accessed 12 May 2007]

Weistroffer, H.R., Smith, C.H. and Narula, S.C. (2005) Multiple criteria decision software. In: Multiple Criteria Decision Analysis: State of
The Art Surveys, Figueira, J., Greco, S., Ehrgott, M. (eds.), Springer Science + Business Media, Inc. Boston eBook.

Wong, W.Y., Zhang, M.D. and Kara-Ali, M. (2000) Negotiating with Experience, Papers from AAAI Technical Report WS-04-00, pp. 85-90. [Online] Workshop, AAAI Press, Available at: http://www.aaai.org/Papers/Workshops/2000/ WS-00-04/WS00-04-013.pdf [accessed 22 September 2008]

Xue, X., Li, X., Shen, Q. and Wang, Y. (2005) An agent based framework for supply chain coordination in construction, Automation in Construction, 14(3), pp. 413-430.

Yen, J., Hu, J. and Bui, T.X. (2000) Intelligent clearinghouse: Electronic marketplace with computer-mediated negotiation supports. In: Proceedings of the 33rd Hawaii International Conference on System Sciences, 1, pp. 10481056.

Young, H.P. (ed.) (1991) Negotiation analysis. Ann Arbor: The University of Michigan Press.

Yuan, Y., Head, M. and Du, M. (2003) The effects of multimedia communication on web-based negotiation, Group Decision and Negotiation, 12(2), pp. 89-109.

Zavadskas, E.K., Peldschus, F., Ustinovičius, L. and Turskis, Z. (2004) Lošimu teorija statybos technologijoje ir vadyboje [Game theory in construction technology and management]. Vilnius: Technika. (In Lithuanian)

Zavadskas, E.K., Kaklauskas, A., Peldschus, F. and Turskis, Z. (2007) Multiattribute assessment of road design solution by applying COPRAS method, Baltic Journal of Road and Bridge Engineering, 2(4), pp. 195-203.

Zavadskas, E.K., Turskis, Z. and Tamošaitiené, J. (2008a) Contractor selection of construction in a competitive environment, Journal of Business Economics and Management, 9(3), pp. 181-187.

Zavadskas, E.K., Kaklauskas, A., Turskis, Z. and Tamošaitienè, J. (2008b) Selection of the effective dwelling house walls by applying attributes values determined at intervals, Journal of Civil Engineering and Management, 14(2), pp. 85-93.

Zlotkin, G. and Rosenschein, J.S. (1996) Mechanisms for automated negotiation in state oriented domains, Journal of Artificial Intelligence Research, 5, pp. 163-238. 


\section{SANTRAUKA}

\section{NEKILNOJAMOJO TURTO DERYBU INTERNETINE SPRENDIMŲ PARAMOS SISTEMA - NAUJOS KARTOS SPRENDIMŲ PARAMOS SISTEMA}

\section{Vita URBANAVIČIENĖ, Artūras KAKLAUSKAS, Edmundas K. ZAVADSKAS, Mark SENIUT}

Derybos yra neatskiriama nekilnojamojo turto pirkimo ir pardavimo proceso dalis. Dabartiniam nekilnojamojo turto sektoriui būdingas intensyvus informacijos, žinių ir automatizavimo naudojimas bei kūrimas (programinè iranga, žiniu ir sprendimu paramos sistemos, neuroniniai tinklai ir pan.). Sutariama, kad geresnis informacijos, žiniu, automatizavimo, taip pat balso streso analizès (biometrinès technologijos) integravimas pagreitina nekilnojamojo turto sektoriaus veikla. Balso streso analizè gali padèti derybininkams atskirti, kada sakoma tiesa, o kada meluojama, padidina priimamų sprendimų naudinguma, paspartina nekilnojamojo turto paieškos ir derybu procesus, padeda pasiekti naudingesnių pirkimo ir pardavimo sutarties sąlygu bei sumažina nekilnojamojo turto paieškos ir derybu proceso kaina. Straipsnio autoriai, siekdami pagerinti sprendimu paramos sistemų kokybę ir efektyvuma, analizuoja mokslininkų atliktų derybų srities tyrimų rezultatus ir pristato sukurta nekilnojamojo turto derybu internetinę sprendimu paramos sistemą su integruota balso streso analizės technologija kaip naujos kartos sprendimų paramos sistema. 